\title{
Utjecaj vremena skladištenja na hematološke parametre u krvi smeđeg medvjeda
} (Ursus arctos)

\author{
N. Hadžimusic*, V. Škapur, D. Rukavina, L. Velić i J. Katica
}

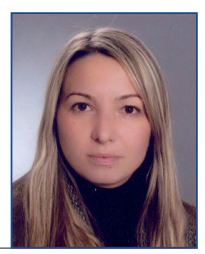

\section{Sažetak}

Na vrijednosti hematoloških parametara značajan utjecaj mogu imati vrijeme uzorkovanja krvi u odnosu na vrijeme analize, ali i uvjeti skladištenja, poput temperature na kojoj se krv transportira do referentnog laboratorija. Odlaganje analize krvi može dovesti do znatnih promjena koje tada direktno utječu na interpretaciju dobivenih podataka te $\mathrm{u}$ konačnici mogu dovesti i do pogrešno postavljene dijagnoze. Poseban izazov u veterinarskoj medicini predstavljaju habitati divljih životinja, poput smeđeg medvjeda, koji se nalaze na velikim udaljenostima od referentnih laboratorija. Stoga je cilj ovog istraživanja bio ispitati promjene nekih hematoloških parametara, i to: vrijednosti broja eritrocita, vrijednosti broja leukocita, hematokritsku vrijednost, vrijednosti sadržaja hemoglobina, vrijednosti veličine prosječnog eritrocita, srednji sadržaj hemoglobina $u$ eritrocitu te srednju koncentraciju hemoglobina $\mathrm{u}$ eritrocitima $\mathrm{u}$ krvi smeđeg medvjeda, a koja je skladištena tijekom 48 sati na različitim temperaturama, odnosno na temperaturi hladnjaka $\left(4{ }^{\circ} \mathrm{C}\right)$ i na sobnoj temperaturi $\left(24{ }^{\circ} \mathrm{C}\right)$. Krv je uzorkovana punkcijom v. jugularis nakon sedacije životinja kombinacijom metomidina, tiletamina i zolazepama. Istraživanjem je obuhvaćeno devet klinički zdravih smeđih medvjeda oba spola, starosti 3-5 godina te je određena vrijednost ispitivanih hematoloških parametara neposredno nakon uzorkovanja $\mathrm{s}$ ciljem određivanja bazičnih vrijednosti. Tijekom ispitivanog razdoblja $\mathrm{u}$ trajanju od 48 sati određene su vrijednosti ispitivanih parametara $\mathrm{u}$ intervalima $(12 \mathrm{~h}, 24 \mathrm{~h}, 36 \mathrm{~h}$ i $48 \mathrm{~h})$ u krvi skladištenoj na različitim temperaturama $\left(4^{\circ} \mathrm{C}\right.$ i $\left.24^{\circ} \mathrm{C}\right)$. Rezultati našeg istraživanja su pokazali da se vrijednosti broja eritrocita i vrijednosti broja leukocita u krvi smeđeg medvjeda nisu statistički značajno razlikovale od bazičnih vrijednosti, ukoliko je krv skladištena na temperaturi od $4{ }^{\circ} \mathrm{C}$, a analiza uzorka izvršena unutar razdoblja od 36 sati; što je određeno i u razdoblju unutar 24 sata od uzorkovanja kada su uzorci krvi pohranjeni na temperaturi od $24{ }^{\circ} \mathrm{C}$. Vrijednost hematokrita nije pokazala statistički značajne razlike unutar 24 sata od uzorkovanja krvi te $u$ navedenom intervalu temperatura skladištenja nije

Dr. sc. Nejra HADŽIMUSIĆ* ${ }^{\text {, dr. med. vet., docentica, (dopisni autor, e-mail: nejra.hadzimusic@vfs.unsa. }}$ ba), Veterinarski fakultet Univerziteta u Sarajevu, Sarajevo, Bosna i Hercegovina; dr. sc. Vedad ŠKAPUR, dr. med. vet., docent, Poljoprivredni fakultet, Univerziteta u Sarajevu, Sarajevo, Bosna i Hercegovina; dr. sc. Dunja RUKAVINA, dipl. biolog., izvanredna profesorica, dr. sc. Lejla VELIĆ, dr. med. vet., izvanredna profesorica, Jasmin KATICA, dr. med. vet., viši asistent, Veterinarski fakultet Univerziteta u Sarajevu, Sarajevo, Bosna i Hercegovina 
značajno utjecala na dobivene rezultate. Vrijednost koncentracije hemoglobina se već nakon 12 sati od uzorkovanja značajno razlikovala od bazičnih vrijednosti. Vrijednosti hematoloških indeksa određene našim istraživanjem pokazuju direktan odraz promjena vrijednosti ispitivanih hematoloških parametara.

Ključne riječi: smeđi medvjed, hematološki parametri, vrijeme skladištenja, temperatura

\section{Uvod}

Hematološka dijagnostika je rutinska metoda procjene zdravstvenog stanja i predstavlja znatan dio kliničkog pregleda. Poznato je da na vrijednosti hematoloških parametara može utjecati niz čimbenika poput: tehnike uzorkovanja krvi, uvjeta skladištenja uzoraka, manipulacije tijekom preanalitične faze, te posebnosti korištene opreme (Uyuklu i sur., 2009.). Zbog značenja koji mogu imati na rezultate hematoloških pretraga, navedeni čimbenici su predmet brojnih studija, čiji rezultati predstavljaju osnovu za izradu pravilnika dobre laboratorijske prakse (engl. Good laboratory practice, GLP). Iako je pretrage krvi poželjno provesti neposredno nakon uzorkovanja, to nije uvijek moguće. Tako uzorkovanje krvi na udaljenim lokacijama zahtijeva transport uzorka do referentnog laboratorija te se tako vrijeme analize krvi značajnije odgađa. Upravo je to slučaj kod uzorkovanja krvi divljih vrsta životinja, pogotovo onih koje se nalaze na manje pristupačnom terenu. Također, zbog posebnosti pojedinih vrsta, automatskim hematološkim analizatorima nije uvijek moguće obraditi uzorak krvi te se uzorak krvi ispituje manuelnim metodama, što dodatno usporava proces analize.

Pravilan transport uzorka krvi, ali i način skladištenja mogu znatno utjecati na rezultate hematoloških pretraga. Tendulkar i sur. (2015.) navode da skladištenje krvi ljudi na temperaturi hladnjaka minimizira morfološke promjene stanica krvi. Istraživanja uzoraka krvi različitih životinjskih vrsta pokazuju značajne razlike u stabilnosti sastojaka krvi na sobnoj i temperaturi hladnjaka. Bleul i sur.
(2002.) u svom istraživanju navode da krv goveda skladištena na temperaturi hladnjaka ima pozitivan utjecaj na vrijednost broja eritrocita, dok nakon $24 \mathrm{~h}$ skladištenja dolazi do smanjenja broja leukocita. Fazio i sur. (2017.), navode istraživanje provedeno u konja, gdje je zapaženo da su hematološki parametri skladišteni na sobnoj temperaturi stabilniji od onih držanih na temperaturi hladnjaka.

Prema našim saznanjima do danas nisu dostupni podatci o utjecaju vremena i temeperature skladištenja na hematološke parametre krvi smeđeg medvjeda. Ovo je istraživanje za cilj trebalo ustvrditi utjecaj različitih temperatura i vremena skladištenja na neke hematološke parametre $u$ krvi medvjeda, odnosno odrediti vremenski raspon od uzorkovanja krvi do analize tijekom kojeg neće nastupiti znatne promjene usljed skladištenja uzoraka krvi, mehanizmi nastanka promjena nisu bili predmetom istraživanja.

\section{Materijali i metode}

Krv je uzorkovana od devet klinički zdravih smeđih medvjeda oba spola, starosti 3-5 godina, držanih u zatočeništvu privatnog Zoo vrta. Medvjedi su procijenjeni klinički zdravim na osnovi tjelesne temperature, frekvencije srčanog rada i frekvencije disanja te tjelesnog pregleda. Starost medvjeda je bila poznata na osnovi službene evidencije. S obzirom da su medvjedi držani u zatočeništvu, krv je uzorkovana u cilju procjene zdravstvenog stanja. Prije uzorkovanja životinje su sedirane kombinacijom metomidina, tile- 
tamina i zolazepama (Fröbert i sur., 2010., Fahlman i sur., 2011.). Krv je uzorkovana punkcijom v. jugularis u epruvete zapremine $4 \mathrm{~mL}, \mathrm{~s}$ antikoaguolansom etilendiaminotratraoctenom kiselinom (EDTA) (Vacuette $^{\circledR}$, Greiner Bio-One International AG, Kremsmünster, Austrija). Neposredno nakon uzorkovanja krvi određene su vrijednosti nekih hematoloških parametara, koje su predstavljale bazične vrijednosti. Svaki uzorak krvi je zatim podijeljen na dva jednaka dijela, gdje je jedan pohranjen na temperaturi hladnjaka $\left(4^{\circ} \mathrm{C}\right)$, a drugi na sobnoj temperaturi $\left(24^{\circ} \mathrm{C}\right)$. Određivanje vrijednosti pojedinih hematoloških parametara izvršeno je tijekom $48 \mathrm{~h}$ (12h, $24 \mathrm{~h}, 36 \mathrm{~h}$ i 48h) u uzorcima pohranjenim na različitim temperaturama.

U uzorcima krvi određivani su sljedeći hematološki parametri: vrijednost broja eritrocita, vrijednost hematokrita (engl. Packed cell volume, PCV), vrijednost broja leukocita i vrijednost sadržaja hemoglobina $(\mathrm{Hgb})$, a izračunate su vrijednosti veličine prosječnog eritrocita (mjera obujma) (engl. Mean corpuscular volume, MCV), srednji sadržaj hemoglobina u eritrocitu (engl. Mean Corpuscular Haemoglobin, $\mathrm{MCH}$ ) i srednja koncentracija hemoglobina $\mathrm{u}$ eritrocitima (engl. Mean cell hemoglobin concentration, $\mathrm{MCHC}$ ) Zbog male količine uzorkovane krvi, vrijednosti hematokrita nisu mogle biti određene 36 sati nakon skladištenja, a posljedično tomu ni vrijednosti $\mathrm{MCV}$ i MCHC.

Vrijednosti broja eritrocita i leukocita određene su korištenjem Neubauerovog hemocitometra (Assistant, Njemačka), dok je hematokritska vrijednost izražena $u$ postotcima (\%) određena mikrohematokritskom metodom, uz korištenje mikrohematokritske centrifuge i čitača (Hawksley, Engleska). Vrijednost koncentracije hemoglobina određena je hemoglobinometrom (Hawksley, Engleska), dok su vrijednosti $\mathrm{MCV}, \mathrm{MCH}$ i MCHC izračunate korištenjem formule.
Rezultati istraživanja predstavljeni su kao srednje vrijednosti sa standardnom pogreškom. Podatci su analizirani korištenjem ANOVA programa, pri čemu se izvršila statistička usporedba bazičnih vrijednosti s vrijednostima tijekom $48 \mathrm{~h}$. Razina signifikantnosti je postavljena na $P<0,05$.

\section{Rezultati}

Vrijednost broja eritrocita određena našim istraživanjem nije pokazala statistički značajne razlike u uzorcima krvi skladištenim na temperaturi $+4{ }^{\circ} \mathrm{C}$ nakon $12 \mathrm{~h}, 24 \mathrm{~h}$ te $36 \mathrm{~h}$ od uzorkovanja u odnosu na bazične vrijednosti $\left(7,24 \pm 0,42 \times 10^{12} / \mathrm{L}\right)$ te je značajan porast vrijednosti broja eritrocita određen tek nakon $48 \mathrm{~h}$, kada je vrijednost broja eritrocita iznosila $9,75 \pm 0,35 \times 10^{12} / \mathrm{L}$ na temperaturi $4{ }^{\circ} \mathrm{C}$. $\mathrm{S}$ druge strane, uzorci krvi skladišteni na sobnoj temperaturi $\left(24{ }^{\circ} \mathrm{C}\right)$ pokazali su signifikantan porast broja već nakon $36 \mathrm{~h}$ od uzorkovanja $\left(4,82 \pm 0,62 \times 10^{12} / \mathrm{L}\right)$ (Graf. 1.). $\mathrm{Na}$ jednak način ponašale su se i vrijednosti broja leukocita, čiji broj se također statistički značajno povećao u odnosu na bazične vrijednosti $\left(5,07 \pm 0,78 \times 10^{9} / \mathrm{L}\right)$ nakon $48 \mathrm{~h}$ u uzorcima skladištenim na $4{ }^{\circ} \mathrm{C}\left(7,73 \pm 0,56 \times 10^{9} / \mathrm{L}\right)$, za razliku od leukocita skladištenih na $24{ }^{\circ} \mathrm{C}$, kada je rast bio već nakon $36 \mathrm{~h}$ $\left(11,12 \pm 2,7 \times 10^{9} / \mathrm{L}\right)$ (Graf. 2.). Međutim, $48 \mathrm{~h}$ nakon uzorkovanja, vrijednost broja leukocita iznosila je $4,77 \pm 2,17 \times 10^{9} / \mathrm{L}$ i nije se značajno razlikovala od bazičnih vrijednosti.

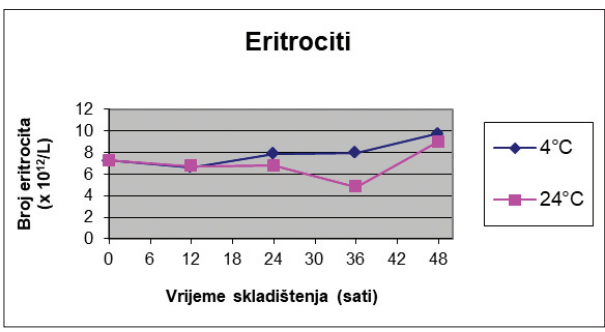

Graf. 1. Vrijednosti broja eritrocita u uzorcima krvi smeđeg medvjeda skladištene na različitim temperaturama tijekom ispitivanog razdoblja 


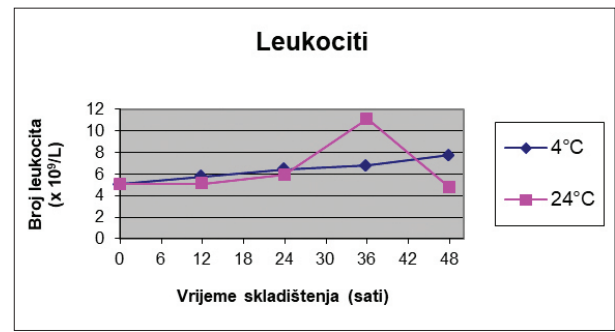

Graf. 2. Vrijednosti broja leukocita u uzorcima krvi smeđeg medvjeda skladištene na različitim temperaturama tijekom ispitivanog razdoblja

Vrijednosti hematokrita određene u uzorcima krvi skladištenjem tijekom 24 sata statistički se nisu značajno razlikovale (Graf. 3.).

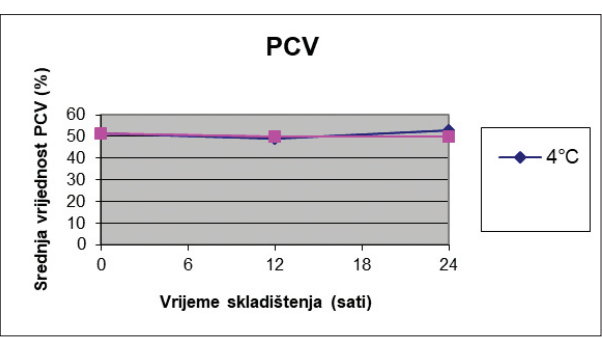

Graf. 3. Vrijednost hematokrita lengl. Packed cell volumel u uzorcima krvi smeđeg medvjeda skladištene na različitim temperaturama tijekom ispitivanog razdoblja

Vrijednost sadržaja hemoglobina statistički se značajno razlikovala od bazičnih vrijednosti $(120 \pm 5,77 \mathrm{~g} / \mathrm{L})$ već nakon $12 \mathrm{~h}$ od skladištenja na temperaturi od $24{ }^{\circ} \mathrm{C}$, kada je određena vrijednost iznosila 220 $\pm 7,32 \mathrm{~g} / \mathrm{L}$. Statistički značajna promjena vrijednosti koncentracije hemoglobina u uzorcima krvi skladištenim na $4{ }^{\circ} \mathrm{C}$ određena je nakon $48 \mathrm{~h}$ i iznosila je 176,67 $\pm 6,01 \mathrm{~g} / \mathrm{L}$ (Graf. 4.).

Vrijednost veličine prosječnog eritrocita (mjera obujma) se statistički značajno razlikovala od bazičnih vrijednosti $(71,09 \pm 1,79$ fL) već nakon 12 sati prilikom skladištenja uzoraka na

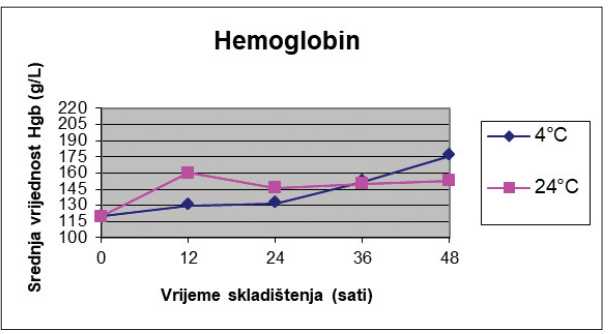

Graf. 4. Vrijednost hemoglobina u uzorcima krvi smeđeg medvjeda skladištene na različitim temperaturama tijekom ispitivanog razdoblja

temperaturi $24^{\circ} \mathrm{C}(88,1 \pm 1,35 \mathrm{fL})$, dok je na temperaturi hladnjaka $\left(4{ }^{\circ} \mathrm{C}\right)$ statistički značajna razlike određena 24 sata od uzorkovanja i iznosila 52,06 $\pm 1,40$ fL (Graf. 5.).

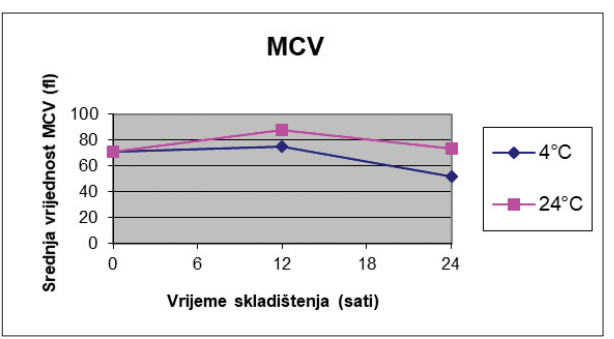

Graf. 5. Vrijednost veličine prosječnog eritrocita (mjera obujma) lengl. Mean corpuscular volume, MCV) u uzorcima krvi smeđeg medvjeda skladištene na različitim temperaturama tijekom ispitivanog razdoblja

Srednji sadržaj hemoglobina $u$ eritrocitu određen našim istraživanjem neposredno nakon uzorkovanja iznosio je 16,59 $\pm 0,18$ pg (Graf. 6.). Vrijednost se ovog parametra tijekom ispitivanog perioda značajno razlikovala te su signifikantne razlike određene već tijekom prvog mjerenja nakon 12 sati i to za uzorke držane na obje temperature skladištenja. Naime, na temperaturi $4{ }^{\circ} \mathrm{C}$ nakon $12 \mathrm{~h}$ određena vrijednost $\mathrm{MCH}$ iznosila je $24,14 \pm 2,68 \mathrm{pg}$, dok je po isteku istog vremenskog razdoblja vrijednost $\mathrm{MCH}$ u uzorcima skladištenim na $24^{\circ} \mathrm{C}$ iznosila $32,71 \pm 0,41 \mathrm{pg}$. 


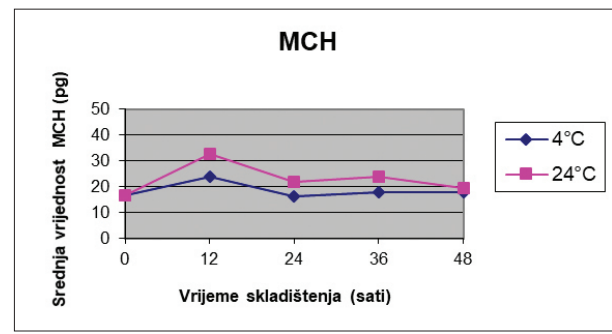

Graf. 6. Srednja vrijednost sadržaja hemoglobina u eritrocitu (engl. Mean Corpuscular Haemoglobin) u uzorcima krvi smeđeg medvjeda skladištene na različitim temperaturama tijekom ispitivanog razdoblja

Srednja vrijednost koncentracije hemoglobina $\mathrm{u}$ eritrocitima $\mathrm{u}$ uzorcima krvi smeđeg medvjeda neposredno nakon uzorkovanja je iznosila 23,36 $\pm 0,47$ g/dL. Već nakon 12 sati od uzorkovanja, vrijednost MCHC je bila značajno povišena, bez obzira na temperaturne uvjete skladištenja (Graf. 7.).

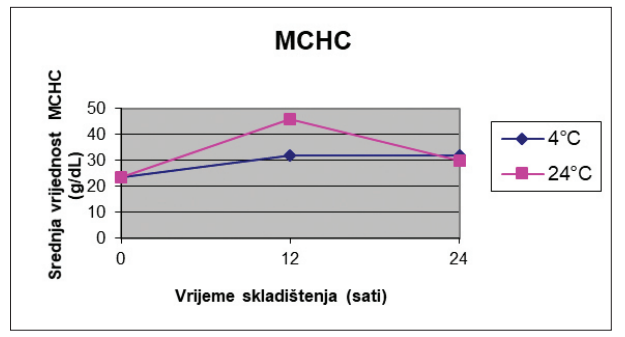

Graf. 7. Srednja vrijednost koncentracije hemoglobina u eritrocitima lengl. Mean cell hemoglobin concentration] u uzorcima krvi smeđeg medvjeda skladištene na različitim temperaturama tijekom ispitivanog perioda

\section{Rasprava}

Vrijednosti hematoloških parametara određene našim istraživanjem pokazale su značajnu ovisnost o temperaturi i vremenu skladištenja. Vrijednost broja eritrocita nije se značajno mijenjala tijekom prvih 36 sati skladištenja u uzorcima držanim na $4{ }^{\circ} \mathrm{C}$ (Graf. 1.). Značajna promjena broja eritrocita nakon 36h uzorkovanja vjerojatno je posljedica evaporacije tekuće frakcije krvi na temperaturi $24{ }^{\circ} \mathrm{C}$, dok porast vrijednosti broja ovih stanica nakon $48 \mathrm{~h}$ u uzorcima skladištenim na $4{ }^{\circ} \mathrm{C}$, upućuje na nešto sporiju evaporaciju na nižim temperaturama. Smanjenje broja eritrocita nakon $36 \mathrm{~h}$ od uzorkovanja u uvjetima ambijenta od $24{ }^{\circ} \mathrm{C}$ vjerojatno je posljedica autolize eritrocita zbog više temperature (Verma i sur., 2015.).

Vrijednost hematokrita određena našim istraživanjem neposredno po uzorkovanju je iznosila 51,33 $\pm 1,85$ $\%$. Tijekom ispitivanog razdoblja $u$ uzorcima skladištenim na $4{ }^{\circ} \mathrm{C}$ zabilježen je nesignifikantan rast ove vrijednosti pa je tako nakon 24 sata skladištenja određena vrijednost hematokrita iznosila $53 \pm 1 \%$ (Graf. 3.). Većina studija ukazuje porast hematokritske vrijednosti usljed, pretpostavlja se, porasta zapremine eritrocita tijekom skladištenja. S druge strane, u uzorcima krvi skladištenim na $24{ }^{\circ} \mathrm{C}$, ustanovljeno je nesignifikantno smanjenje hematokritske vrijednosti $(50 \pm 4,04 \%)$, što korespondira $\mathrm{s}$, nesignifikantnim smanjenjem broja eritrocita $\mathrm{u}$ istim uvjetima skladištenja. Niže vrijednosti hematokrita nakon $24 \mathrm{~h}$ skladištenja ustanovili su i Wood i sur. (1999.) prilikom ispitivanja stabilnosti hematoloških parametara $u$ zavisnosti od temperature i vremena skladištenja u ljudi. Smanjenje broja eritrocita tijekom skladištenja je vjerojatno posljedica spontane hemolize. Zbog male količine uzorka, hematokrit je određen samo unutar perioda od 24 sata.

Značajan porast sadržaja hemoglobina određen je već 12 sati nakon skladištenja, i to i u uzorcima krvi skladištenim na temperaturi $4{ }^{\circ} \mathrm{C}$ i $24{ }^{\circ} \mathrm{C}$, kada je određena vrijednost iznosila 156,66 $\pm 6,66$ g/L, odnosno 220 7,32 g/L (Graf. 4.).

Srednja vrijednost MCV određena neposredno nakon uzorkovanja krvi (BV) iznosila je 71,09 $\pm 1,79$ fL (Graf. 5.). Statistički značajne razlike određene su već nakon 12 sati u krvi skladištenoj 
na temperaturi $24{ }^{\circ} \mathrm{C}$, dok je u uzorcima krvi držanim na temperaturi hladnjaka statistički značajno niža vrijednost $(52,06 \pm 1,4$ fL) određena nakon 24 sata skladištenja. Dostupni podatci navode velike razlike i široke referentne raspone ovog parametra u smeđih medvjeda. Tako Seal i sur. (1967.) navode širok raspon za MCV (12-132 fL). Nije poznato vrijeme koje je proteklo od uzorkovanja do određivanja ovog parametra $u$ navedenoj studiji. U nešto novijoj studiji Kusak i sur. iz 2005. godine raspon određen za MCV je nešto uži i kreće se u rasponu od 52,99-90,88 fL, sa srednjom vrijednošću od $71,9 \pm 1,26$ fL. S obzirom da je vrijednost MCV određena preračunom hematokritske vrijednosti i broja eritrocita, te su ove vrijednosti direktno utjecale na vrijednost MCV određenih našim istraživanjem.

Porast vrijednosti MCV ustanovljen našim istraživanjem u uzorcima krvi skladištenim na temperaturi $24{ }^{\circ} \mathrm{C}$ je vjerojatno odraz nabreknuća eritrocita te ukazuje da je porast vrijednosti ovog parametra moguće izbjeći ukoliko se uzorak krvi skladišti na temperaturi hladnjaka unutar 12 sati od uzorkovanja. Slična zapažanja dokumentirali su i Turhan i sur. (2011.) u uzorcima krvi u ljudi.

Srednji sadržaj hemoglobina u eritrocitima određen našim istraživanjem neposredno nakon uzorkovanja iznosio je $16,58 \pm 0,18$ pg, što je niža vrijednost od zabilježene u radu Kusak i sur. (2005.). Vrijednosti su se značajno razlikovale već unutar ispitivnog razdoblja od 12 sati, za obje temperature skladištenja. S obzirom da se vrijednosti hematoloških indeksa, MCH i MCHC, određuje dijeljenjem vrijednosti hemoglobina i broja eritrocita, odnosno sadržaja hemoglobina i hematokritske vrijednosti, bilo kakve promjene vrijednosti sadržaja hemoglobina, broja eritrocita, odnosno hematokritske vrijednosti, utjecat će na vrijednost ispitivanih indeksa. Navedeno korespondira s rezultatima koje smo odredili za vrijednosti sadržaja hemoglobina, koje su se već nakon 12 sati značajno razlikovale od vrijednosti određenim neposredno po uzorkovanju krvi pa tako ni vrijednosti $\mathrm{MCH}$ i MCHC ne možemo smatrati pouzdanim, ukoliko se ne odrede neposredno po uzorkovanju, bez obzira na temperaturu skladištenja.

Sukladno rezultatima našeg istraživanja možemo zaključiti da uzorci krvi skladišteni 48 sati ne mogu pružiti pouzdane rezultate za vrijednosti hematoloških parametara krvi smeđeg medvjeda. Pouzdane laboratorijske vrijednosti imaju eritrociti i leukociti, ukoliko je krv skladištena na temperaturi od $4{ }^{\circ} \mathrm{C}$, a analiza uzorka izvršena do 36 sati, odnosno pokazuju stabilnost 24 sata na temperaturi skladištenja $24{ }^{\circ} \mathrm{C}$. Hematokritska vrijednost je pouzdana ukoliko se odredi unutar 24 sata, što je bilo razdoblje unutar kojeg smo jedino našim istraživanjem i odredili vrijednost ovog parametra. Najmanja stabilnost ispitivanih hematoloških parametara određenajekod vrijednosti hemoglobina. Naime, vrijednosti sadržaja hemoglobina već nakon 12 sati nisu odgovarale vrijednostima određenih neposredno po uzorkovanju krvi, bez obzira na uvjete ambijenta. Vrijednost hematoloških indeksa određene su preračunavanjem hematoloških parametara, koji su podložni utjecaju temperature i vremena skladištenja. Promjene navedenih parametara kroz vrijeme i temperaturu skladištenja direktno utječu na vrijednosti određivanih indeksa te su znatno manje pouzdani, ukoliko se analiza krvi ne učini neposredno po uzorkovanju.

Rezultati našeg istraživanja mogu se koristiti kao uputstva u pravcu adekvatnog skladištenja i rukovanja uzorcima krvi smeđeg medvjeda. 
Smatramo da je od posebnog značenja poznavanje stabilnosti pojedinih parametara hematološkog profila, s obzirom da se divlje životinje nalaze na velikim udaljenostima od referentnih laboratorija. Osim udaljenosti, na pravovremenu analizu utječu i osobenosti uzorkovanja krvi divljih životinja pa tako i smeđih medvjeda. Isto tako, treba imati na umu da uzorkovanje krvi kod medvjeda, ali i ono što prethodi (obuzdavanje životinje, sedacija primjenom anestetika) može utjecati na rezultate hematoloških parametara, što predstavlja samo jedan dio izazova u studijama koje se bave divljim životinjama.

\section{Literatura}

1. FAHLMAN, Å., J. M. ARNEMO, J. E SWENSON, J. PRINGLE, S. BRUNBERG and G. NYMAN (2011): Physiologic evaluation of capture and anesthesia with medetomidine-zolazepam-tiletamine in brown bears (Ursus arctos). J. Zoo Wildlife Med. 42, 1-11.

2. FAZIO, F., V. FERRANTELLI, C. SAOCA, G. GIANGROSSO and G. PICCIONE (2017): Stability of haematological parameters in stored blood samples of rainbow trout Oncorhynchus mykiss (Walbaum, 1792). Vet. Med. 62, 401-405.
3. FRÖBERT, O., K. CHRISTENSEN, A. FAHLMAN, S BRUNBERG S., J. JOSEFSSON, E. SÄRNDAHL and J. M. ARNEMO (2010): Platelet function in brown bear (Ursus arctos) compared to man. Thromb. J. 8, 11.

4. KUSAK, J., R. BARIĆ RAFAJ, Z. ŽVORC, D. HUBER, J. FORŠEK, L. BEDRICA and V. MRLJAK (2005): Effects of Sex, Age, Body Mass, and Capturing Method on Hematologic Values of Brown Bears in Croatia. J. Wildl. Dis. 41, 843-847.

5. SEAL, U. S., W. R. SWAIM and A. W. ERICKSON (1967): Hematology of the ursidae. Comp. Biochem. Physiol. 22, 451-460.

6. TENDULKAR, A., J. PUNEET, G. SUMEET, T. MANISHA, K. RAVINDRA and G. BALA (2015): Stability of Selected Hematological Parameters in Stored Blood Samples. J. Cell Sci. Ther. 6:5.

7. TURHAN, T., S. SEZER, C. YÜCEL and Y. KOCA (2011): Effects of Storage Conditions on Complete Blood Cell Count Parameters. Turk. J. Biochem. 36, 165-174.

8. UYUKLU, M., M. CENGIZ, P. ULKER, T. HEVER, J. TRIPETTE, P. CONNES, N. NEMETH, H. J. MEISELMAN and O. K. BASKURT (2009): Effects of storage duration and temperature of human blood on red cell deformability and aggregation. Clin. Hemorheol. Microcirc. 41, 269-278.

9. VERMA, M., K. DAHIYA, D. MALIK, P. K. SEHGAL and R. DEVI (2015): Effect of blood storage on complete biochemistry. J. Blood Disord. Transfus. 6, 1-4.

10. WOOD, B., J. ANDREWS, S. MILLER and D. E SABATH (1999): Refrigerated Storage Improves the Stability of the Complete Blood Cell Count and Automated Differential. Aw. J. Clin. Pathol. 112, 687-691. 


\section{Effects of storage conditions on hematological parameters of Brown bear (Ursus arctos)}

Nejra HADŽIMUSIĆ, DVM, PhD, Assistant Professor, Veterinary Faculty, University of Sarajevo, Sarajevo, Bosnia and Herzegovina; Vedad ŠKAPUR, DVM, PhD, Assistant Professor, Faculty of Agriculture and Food Sciences, University of Sarajevo, Sarajevo, Bosnia and Herzegovina; Dunja RUKAVINA, Biologist, PhD, Associate Professor, Lejla VELIĆ, DVM, PhD, Associate Professor, Jasmin KATICA, DVM, Senior Assistant, Veterinary Faculty, University of Sarajevo, Sarajevo, Bosnia and Herzegovina

Hematology results are often influenced by the time of blood sampling and analysis, and storage conditions such as temperature during delivery of the sample to the laboratory. Delay of blood analysis may lead to hematological changes that affect interpretation of the data, but may also lead to misdiagnosis. The remote habitats of wild animals, such as bears, pose specific challenges. The aim of this study was to investigate changes in certain hematology parameters (red blood cell count, white blood cell count, packed cell volume, hemoglobin concentration, mean cell (corpuscular) volume, mean cell hemoglobin and mean cell hemoglobin concentration) in the blood samples of brown bears under varying storage conditions (i.e. time and temperature). Blood samples were collected by venipuncture of the jugular vein. Brown bears were sedated prior to collection with combination of metodimidine, tiletamine and zolazepame. Blood samples were stored during 48 hours at two different temperatures $\left(4{ }^{\circ} \mathrm{C}\right.$ or $\left.24^{\circ} \mathrm{C}\right)$. Blood samples were collected from nine clinically healthy brown bears of both sexes, aged 3 to 5 years. Hematological determinations were conducted on the blood samples immediately upon collection to obtain the baseline value (BV) and thereafter at specific time intervals $(12 \mathrm{~h}, 24 \mathrm{~h}, 36 \mathrm{~h}$ and $48 \mathrm{~h})$ during the storage time for blood samples stored at each temperatures $\left(4^{\circ} \mathrm{C}\right.$ or $\left.24^{\circ} \mathrm{C}\right)$. The results showed that brown bear blood samples provided legitimate results for red blood cell count stored at $4{ }^{\circ} \mathrm{C}$ for up to 36 hours, and for white blood cell counts stored at $24{ }^{\circ} \mathrm{C}$ for up to 24 hours. Legitimate results were obtained for packed cell volume provided at both temperatures for up to 24 hours. Hemoglobin concentration showed significant difference after only 12 hours of storage at both temperatures. The values of hematological indices determined here reflect the changes of the tested hematological parameters.

Key words: Brown bear; hematology parameters; duration of storage; temperature 